\title{
EFFECT OF RAW AND FERMENTED WHEAT GERM ON OXIDATIVE AND IMMUNE STRESS INDUCED BY CARBON TETRACHLORIDE (CCL4) HEPATIC TOXICITY IN RATS
}

\author{
By \\ Mohamed Sabry Abdelbaky \\ Nutrition and Food Science Dept., \\ Faculty of Home Economics, \\ Helwan University
}

Research Gournal Specific Education

Faculty of Specific Education

gMansoura University

ISSUE NO. 26, YULY. 2012

مجلة بحوث التربية النوعية - جامعة المنصورة

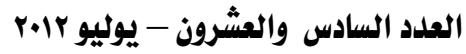




\title{
EFFECT OF RAW AND FERMENTED WHEAT GERM ON OXIDATIVE AND IMMUNE STRESS INDUCED BY CARBON TETRACHLORIDE (CCL4) HEPATIC TOXICITY IN RATS
}

\author{
Mohamed Sabry Abdelbaky"
}

\begin{abstract}
The present study was performed to evaluate the effect of wheat germ and fermented wheat germ on some Immunoglobulin's productions, lipids profile and liver functions in cirrhotic rats by carbon tetrachloride (Ccl4) . Rats were divided into eight groups, control groups (1\&2) negative and positive were fed on basal diet without supplementation. All treated cirrhotic groups (3-8 ) were fed on experimental diets with raw or fermented wheat germ by different levels $(5,10 \& 15 \%)$. Results clearly revealed that fermented wheat germ recorded the highest values content in Vitamin (A), (E) and (C), compared with raw wheat germ . The best treatment were fermented wheat germ $(15 \%)$ and raw wheat germ $(15 \%)$ which had lowest values of total lipid, triglycerides, total cholesterol LDL , VLDL , AST , ALT and had the highest values of HDL , respectively. While, all groups fed on fermented wheat germ by different levels $(5$, $10,15 \%)$ had the highest values of serum level of interferon gamma (INF-y) and interleukin -10 (IL-10) respectively . It could be concluded that wheat germ and fermented wheat germ improve some Immunoglobulin's production, lipids profile and liver functions especially fermented wheat germ 10 and $15 \%$ which has the best significant protective effect against acute hepatotoxicity induced by carbon tetrachloride (Ccl4) in rats.
\end{abstract}

Key Word: fermented wheat germ - cirrhosis - CCl4 - liver oxidative stress - immune 


\title{
EFFECT OF RAW AND FERMENTED WHEAT GERM ON OXIDATIVE AND IMMUNE STRESS INDUCED BY CARBON TETRACHLORIDE (CCL4) HEPATIC TOXICITY IN RATS
}

\author{
Mohamed Sabry Abdelbaky" \\ INTRODUCTION :
}

Reactive oxygen species (ROS) are constantly generated in vivo for physiological purposes. Their productions are often balanced by antioxidant defense system. However, excess ROS production beyond the ability of antioxidant defense system can cause oxidative damage to protein, lipid and nucleic acid (1) . Antioxidant defense include antioxidant enzymes such as superoxide dismutase (SOD), catalase (CAT) and glutathione peroxidase (GPx), in addition to low molecular agents and dietary antioxidants. Disturbing of oxidant-antioxidant balance system is involved in development of many chronic diseases (2) .

Liver, largest organ in the body is being involved to maintain the body's internal milieu and also protect itself from the challenges it faces during its functioning. Since it is involved in the biochemical conversions of various endogenous and exogenously administered substances, there is a possibility of generating various highly reactive species of free radicals. In spite of this free radicals generated by hepatotoxins like carbon tetrachloride (Cc14) may overpower the protective mechanism of the liver and cause hepatic damage. Though the modern medicinal system has grown phenomenally, the drug for treating hepatic disease is still a dream. Hence, people are looking at traditional systems of medicines for remedies to hepatic disorders (3).

Wheat germ, being a by-product of the flour milling industry is one of the most potential and excellent sources of vitamins, minerals, fiber and proteins at a relative low cost (4) . In addition to, wheat germ is the richest known natural source of tocopherols and also abundant in B-group vitamins (5). Wheat germ protein has been classed with effectively better animal proteins and is rich in seventeen amino acids, especially the essential amino acids lysine, methionine and threonine, in which many cereals are deficient (6).

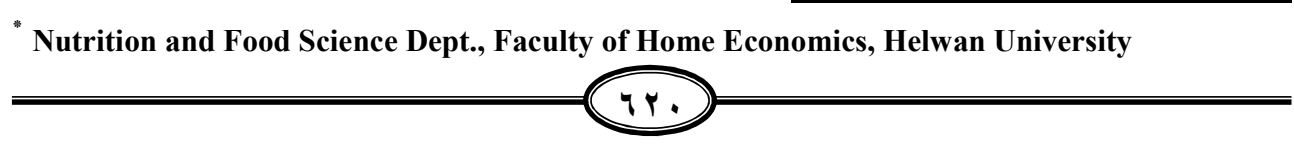


Wheat germ is rich in polyunsaturated fats $(\sim 12 \%)$, mainly oleic, linoleic, and $\alpha$ - linolenic acids, and vitamins, especially vitamin $\mathrm{E}, \mathrm{A}$ and $\mathrm{B}$. Its protein content is $\sim 28 \%$ and hence wheat germ is a source of essential amino acids with improved nutritional potential if compared to other cereal products(7). Whole grain, such as wheat germ are rich sources of phytochemicals including phenolics, carotenoids, vitamin E, lignans, $\beta$ glycan, inulin, resistant starch sterol and phytates(8). Plant based foods contain significant amount of bioactive phytochemicals, which when consumed together may have a synergistic affect that goes beyond the basic individual function of each single component in combating diseases (8). Wheat germ is therefore sensitive to oxidation that may cause destruction of essential fatty acids and vitamins. Oxidation could be prevented, and shelf life prolonged, by inactivating its enzyme contents by heat treatment or by removing the oil fraction from wheat germ by extraction, or combined techniques (9-12).

There are two types of antioxidants: antioxidant enzymes and nonenzymatic, antioxidant including vitamins $\mathrm{E}$ and $\mathrm{C}$, caroteins and phytochemicals. They work by intercepting and stabilizing the reactive oxygen species. Adequate vitamin and mineral intake is necessary for an optimally functioning immune system. Deficiencies and/or excesses of these nutrients can alter the immune response(10).

The present study was performed to evaluate the effect of wheat germ and fermented wheat germ on some Immunoglobulin's production, lipids profile, liver functions and kidney functions in cirrhotic rats induced by carbon tetrachloride $(\mathrm{Ccl} 4)$.

\section{Materials and Methods}

\section{Wheat germ:}

Wheat germ Giza 60 were obtained from Agricultural Research Centre, Ministry of Agriculture Cairo, Egypt. It was washed, dried and ground. Powdered wheat germ was used in the present study.

\section{Preparation of fermented wheat germ powder :}

$100 \mathrm{~g}$ of Wheat germ powder was fermented using $30 \mathrm{~g}$ of Saccharomyces cerevisiae (baker's yeast) for 48 hours and the paste was filtrated and concentrated using rotary evaporator and stored at room temperature. 


\section{Chemicals:}

Carbon tetrachloride (Cc14) was obtained from El-Gomhorya Company for Chemical and Pharmaceutical, Cairo, Egypt.

Kits for biochemical analysis were purchased from the Gamma Trade Company for Pharmaceutical and Chemicals, Dokki, Egypt.

\section{Experimental animals :}

Male Sprague-Dawley rats weighing $200+10 \mathrm{~g}$ were purchased from Farm of experimental animals in Helwan, Egypt.

\section{Preparation of basal diet .}

The basal diet consisted of protein (13\%), fat (4\%), salt mixture $(3.5 \%)$, vitamin mixture $(1 \%)$, choline $(0.2 \%)$, cellulose $(5 \%)$ and the remainder was $\operatorname{starch}(13)$.

\section{Experimental design:}

A total of forty male healthy rats, weighing between $(200+10 \mathrm{~g})$ were divided into eight groups . To induce cirrhosis all rats except control negative were injected subcutaneously by carbon tetrachloride $(\mathrm{Ccl} 4)$, diluted by paraffin oil (1:1) \{ in a dose of $2 \mathrm{ml} / \mathrm{kg}$ of body weight of rat\}, twice in the week during the experimental feeding period ( 8 weeks ) according to the method described by (Wilfried,et al.,1994) (14); Each group containing 5 rats . Control groups (1\&2) negative and positive were fed on basal diet without supplementation . all treated cirrhotic groups (3:8) were fed on experimental diets as the following :

- Group (3): Fed on basal diet containing 5\% wheat germ.

- Group (4): Fed on basal diet containing 5\% fermented wheat germ.

- Group (5): Fed on basal diet containing $10 \%$ wheat germ.

- Group (6): Fed on basal diet containing $10 \%$ fermented wheat germ.

- Group (7): Fed on basal diet containing $15 \%$ wheat germ.

- Group (8): Fed on basal diet containing $15 \%$ fermented wheat germ.

\section{Blood sampling.}

At the end of the experimental period ( 8 weeks), rats were starved for $12 \mathrm{hr}$., then sacrificed under ether anesthesia. Blood samples were collected from the aortic vein into clean dry centrifuge tubes and were stored at room temperature for 15 minutes, put into a refrigerator for 2 hour 
, then centrifuged for 10 minutes at $3000 \mathrm{rpm}$ to separate serum. Serum was carefully aspirated and transferred into dry clean Wasser -man tubes by using a Pasteur pipette and kept frozen at (-20c) till analysis .

\section{Biological Determination :}

Determination of food intake, body weight gain and feed efficiency ratio: Food Intake (FI) was calculated every other day, The biological value of the different diets was assessed by the determination of its effect on Body Weight Gain (BWG) and Feed Efficiency Ratio (FER) at the end of the experimental period using the following formulas:

$\mathrm{BWG}=$ Final body weight - Initial body weight

$\mathrm{FER}=\mathrm{BWG}(\mathrm{g}) /$ Food consumed $(\mathrm{g})$

\section{Chemical methods:}

Determination of vitamin contents:

Determination of vitamin A, E and C were determined according to Klimes and Jedlicka, 2005(38).

\section{Biochemical Determination :}

\section{Determination of total Lipids :}

Total Lipids (TL) were determined colorimetrically using sulfophosphovanillic mixture according to the method described by Schmitc , $1964(20)$.

\section{Determination of total cholesterol}

Serum cholesterol was determined according to the enzymatic method described by Allain et al.,1974 (15) .

\section{Determination of triglycerides}

The triglycerides in serum were colorimetrically determined according to Wahlefeld, 1974 (16) .

\section{Determination of high density lipoprotein (HDL) cholesterol :}

The HDL-c was determined according to Albers et al., 1983 (17) .

\section{Determination of very low density lipoprotein (VLDL) cholesterol}

The concentration of VLDL-c was estimated according to the Fridewald's equation Fridewald et al., 1972(18) . 
VLDL-c $=$ triglycerides / 5

Determination of low density lipoprotein (LDL) cholesterol :

According to Fridewald et al., 1972 (18) , low density lipoprotein cholesterol can be calculated as follows :

$$
\text { LDL-c }=\text { Total cholesterol }-(\text { HDL-c) }-(\text { VLDL-c) } .
$$

\section{Determination of liver functions :}

Serum activities of aspartate amino transferase AST, alanine amino transferase ALT Alkaline Phosphatase (ALP) activities were measured according to the method described by Reitman and Frankel (1957) (21) .

\section{Determination of kidney functions :}

Serum urea nitrogen, uric acid, creatinine were determined according to the methods described by Patton and Crouch, (1977) (22), Fossati et al., (1980) (23) and Husdan and Rapoport, (1968) (24) respectively.

\section{Determination of interferon gamma (IFN- $\gamma)$ and interleukin-10 (IL-10)}

Serum levels of IFN- $\gamma$ were determined by Human Interferon Gamma (Hu-IFN- $\gamma$ ) ELISA Kit (25 -28) .Serum levels of IL-10 were determined by Human IL-10 Colorimetric ELISA Kit (29- 36) .

\section{Histopathological Examination:}

Specimens from the liver was taken immediately after sacrificing the rats and immersed in 10\% neutral buffered formalin. The fixed specimens were then trimmed, washed, and dehydrated in ascending grades of alcohol, then cleared in xylene, embedded in paraffin, sectioned at 4-6 micron thickness and stained with Hematoxylen and Eosin (Carleton, 1979) (37) and examined microscopically.

\section{Statistical Analysis :}

The obtained data were statistically analyzed according to SAS, 1996 (19). 


\section{Results and Discussions}

Table (1): Vitamins content of raw and fermented wheat germ.*

\begin{tabular}{|l|c|c|c|}
\hline \multicolumn{1}{|c|}{ Treatments } & $\begin{array}{c}\text { Vitamin(A) } \\
\text { IU/g }\end{array}$ & Vitamin (E) IU/g & Vitamin (C) mg/g \\
\hline \hline Raw wheat germ & 103.5 & 13 & 0.95 \\
\hline $\begin{array}{l}\text { Fermented wheat } \\
\text { germ. }\end{array}$ & 159.54 & 15.5 & 1.3 \\
\hline
\end{tabular}

*Mean of three replicates.

Wheat germ is a rich source of antioxidants that include carotenoids, tocopherols, flavonoids and phenolics acids(42). Most of the essential amino acids from wheat germ proteins are present at concentrations higher than in the reference egg protein pattern (43).

Since the rapid increase of the global demand for protein consumption, wheat germ may represent one of the most attractive and alternative source of proteins from cheap vegetable sources (44). Wheat germ is also rich in unsaturated fatty acids, mainly oleic, and $\alpha$-linoleic acids (7), and in functional phytochemicals, mainly flavonoids, sterols, octacosanols and glutathione (44). Data in table (1) showed vitamins content of raw and fermented wheat germ . Results clearly revealed that fermented wheat germ recorded the highest values in Vitamin (A), (E) and (C), compared with raw wheat germ .

Oxidative stress caused by various agents (toxins, metals, dioxin and pesticides) is considered as an imminent threat for many organisms since it can lead to death. However, the imbalance between production of oxygen free radicals (OFRs) and antioxidant defenses in the body is called oxidative stress which has important health implications (39). If there are too many OFRs or too few antioxidants for protection, a condition of oxidative stress develops, which may cause chronic damage (40). The components associated with such antioxidant defense mechanism are altered under the influence of organophosphorus pesticides and that lipid peroxidation is one of the molecular mechanisms involved in pesticide induced cytotoxicity (41). Also, there is a possibility of generating various highly reactive species of free radicals. In spite of this free radicals generated by hepatotoxins like carbon tetrachloride $(\mathrm{Ccl} 4)$ may overpower the protective mechanism of the liver and cause hepatic damage (3). 
The effect of raw and fermented wheat germ on food intake (FI), body weight gain ratio $(\mathrm{BWG} \%)$ and food efficiency ratio (FER) were illustrated in table (2).

Table (2): Effect of raw and fermented wheat germ on food intake, BWG \% and FER (mean +SD).

\begin{tabular}{|c|c|c|c|}
\hline Groups & $\begin{array}{l}\text { Food intake } \\
\text { g/day }\end{array}$ & BWG \% & FER \\
\hline 1- Control Negative & 21.35 & $55.33 \pm 3.24 \mathrm{a}$ & $0.22 \pm 0.07 \mathrm{a}$ \\
\hline 2- Control Positive & 20.85 & $34.22 \pm 2.56 \mathrm{~b}$ & $0.16 \pm 0.06 \mathrm{~b}$ \\
\hline 3-Raw wheat germ $(5 \%)$ & 20.40 & $52.33 \pm 1.75 \mathrm{a}$ & $0.26 \pm 0.012 \mathrm{a}$ \\
\hline $\begin{array}{l}\text { 4- Fermented wheat germ } \\
(5 \%)\end{array}$ & 20.11 & $54.91 \pm 2.34 \mathrm{a}$ & $0.23 \pm 0.08 \mathrm{a}$ \\
\hline 5- Raw Wheat germ $(10 \%)$ & 19.99 & $51.66 \pm 1.87 \mathrm{a}$ & $0.23 \pm 0.07 \mathrm{a}$ \\
\hline $\begin{array}{l}\text { 6- Fermented wheat germ } \\
(10 \%)\end{array}$ & 20.50 & $53.45 \pm 2.98 \mathrm{a}$ & $0.21 \pm 0.09 \mathrm{a}$ \\
\hline 7- Raw Wheat germ (15\%) & 19.88 & $51.73 \pm 1.59 \mathrm{a}$ & $0.23 \pm 0.08 \mathrm{a}$ \\
\hline $\begin{array}{l}\text { 8- Fermented wheat germ } \\
(15 \%)\end{array}$ & 21.58 & $53.89 \pm 2.31 \mathrm{a}$ & $0.25 \pm 0.07 \mathrm{a}$ \\
\hline \multicolumn{4}{|c|}{$\begin{array}{l}\text { * Values with the same letters indicate non- significant difference }(\mathrm{P}<0.05) \text { and } \\
\text { vice versa. }\end{array}$} \\
\hline \multicolumn{3}{|c|}{$\begin{array}{l}\text { BWG\% : Body weight gain ratio } \\
\text { efficiency ratio }\end{array}$} & FER : Food \\
\hline
\end{tabular}

It could be observed that cirrhotic rats (control positive group ) had significant decrease in body weight gain $(\mathrm{BWG} \%)$ and food efficiency ratio (FER) compared with the control negative group . Our findings are similar to the results of Mansour and Mossa, (2010) (45) who reported that oral administration of Chlorpyrifos (CPF) at different doses to lactating rats resulted in significant decrease, in body weight as well as reduction of food intake.

Moreover, our results observed that all cirrhotic groups fed on basal diet with raw or fermented wheat germ by different levels $(5,10$ and $15 \%)$ had significant increase in body weight gain (BWG\%) and food efficiency ratio (FER) compared with control positive rats. These results are in agreement with Gregorio et al., (2001) (46).

Data in table (3), it could be observed that cirrhotic rats (control positive group ) had significant increase in serum total lipid, triglycerides 
and total cholesterol compared with control negative rats. Also, it could be observed that all cirrhotic groups fed on basal diet containing raw or fermented wheat germ by different levels $(5,10$ and 15\%) had significant decrease in total lipid, triglycerides and total cholesterol compared with control positive group of rats.

Table (3): Effect of raw and fermented wheat germ on serum total lipid, triglycerides and total cholesterol (mean $+\mathrm{SD})$.

\begin{tabular}{||l|c|c|c||}
\hline \multicolumn{4}{|c|}{ Parameters as Mean \pm SD } \\
\hline \hline Groups & $\begin{array}{c}\text { Total lipid } \\
(\mathrm{mg} / \mathrm{dl})\end{array}$ & $\begin{array}{c}\text { Triglycerides } \\
(\mathrm{mg} / \mathrm{dl})\end{array}$ & $\begin{array}{c}\text { Total cholesterol } \\
(\mathrm{mg} / \mathrm{dl})\end{array}$ \\
\hline \hline 1- Control Negative & $315.45 \pm 2.15 \mathrm{c}$ & $39.43 \pm 2.44 \mathrm{c}$ & $69.98 \pm 2.65 \mathrm{c}$ \\
\hline 2- Control Positive & $391.55 \pm 2.10 \mathrm{a}$ & $69.88 \pm 2.66 \mathrm{a}$ & $110.21 \pm 2.32 \mathrm{a}$ \\
\hline 3-Raw wheat germ (5\%) & $339.54 \pm 1.70 \mathrm{~b}$ & $57.89 \pm 1.90 \mathrm{~b}$ & $89.29 \pm 2.69 \mathrm{~b}$ \\
\hline 4- Fermented wheat germ (5\%) & $334.54 \pm 2.66 \mathrm{~b}$ & $53.65 \pm 1.89 \mathrm{~b}$ & $79.98 \pm 2.51 \mathrm{~b}$ \\
\hline 5- Raw Wheat germ (10\%) & $329.66 \pm 2.89 \mathrm{~b}$ & $46.66 \pm 2.88 \mathrm{~b}$ & $82.00 \pm 2.99 \mathrm{~b}$ \\
\hline 6- Fermented wheat germ (10\%) & $327.67 \pm 2.33 \mathrm{~b}$ & $47.35 \pm 2.47 \mathrm{c}$ & $74.54 \pm 176 \mathrm{c}$ \\
\hline 7- Raw Wheat germ (15\%) & $319.14 \pm 1.83 \mathrm{c}$ & $41.55 \pm 1.97 \mathrm{c}$ & $73.57 \pm 2.64 \mathrm{c}$ \\
\hline 8- Fermented wheat germ (15\%) & $314.14 \pm 1.74 \mathrm{c}$ & $38.95 \pm 2.69 \mathrm{c}$ & $71.44 \pm 2.33 \mathrm{c}$ \\
\hline \hline
\end{tabular}

* Values with the same letters indicate non significant difference $(\mathrm{P}<0.05)$ and vice versa.

The best treatment were fermented wheat germ (15\%) and raw wheat germ $(15 \%)$ which had lowest values of total lipid, triglycerides and total cholesterol. Similar results were found in the study of Lairon et al., (1987) established that the addition of $7 \%$ wheat germ to a high-fat and highcholesterol diet improved lipoprotein in rats (48). The inclusion of wheat germ in a test meal reduced plasma chylomicron cholesterol concentrations by $27.1 \%$ over several hours in 6 normolipidemic subjects (49). These data suggest that wheat germ may delay the absorption of cholesterol and hence may lower circulating cholesterol. However, the exact mechanism of cholesterol lowering effect by wheat germ is not known. It has been thought that some effects on cholesterol metabolism might be mediated by dietary fiber in the wheat germ (49) .

However, several other mechanisms have been proposed by Borel et al., (1989) who reported that in rats, the absorption of labeled triacylglycerol and cholesterol was both delayed and reduced by wheat germ and other wheat fractions in part as a result of the inhibition of pancreatic lipase and the reduction in triacylglycerol lipolysis (47). Soluble protein 
components of wheat germ are known to inhibit pancreatic lipase activity (50), and partially defatted wheat germ increases the fecal excretion of bile acids in rats (51). Therefore, the mechanism of reducing cholesterol by the use of wheat germ is likely to be complex.

Data in table (4), it could be observed that cirrhotic rats (control positive group ) had significant increase in serum low density lipoprotein LDL , very low density lipoprotein vLDL and decrease in serum high density lipoprotein HDL comparing with control negative.

Table (4): Effect of raw and fermented wheat germ on serum LDL-C, HDL-C and VLDL-C (mean +SD).

\begin{tabular}{|c|c|c|c|}
\hline \multicolumn{4}{|l|}{ Parameters as Mean \pm SD } \\
\hline Groups & $\begin{array}{l}\text { LDL- } \\
\mathrm{C}(\mathrm{mg} / \mathrm{dl}) \\
\end{array}$ & $\mathrm{HDL}-\mathrm{C}(\mathrm{mg} / \mathrm{dl})$ & $\begin{array}{l}\text { VLDL- } \\
\mathrm{C}(\mathrm{mg} / \mathrm{dl}) \\
\end{array}$ \\
\hline 1- Control Negative & $33.53 \pm 2.55 \mathrm{c}$ & $28.56 \pm 1.77 \mathrm{a}$ & $7.89 \pm 1.64 \mathrm{c}$ \\
\hline 2- Control Positive & $72.76 \pm 2.98 \mathrm{a}$ & $23.47 \pm 2.55 \mathrm{~b}$ & $13.98 \pm 1.76 \mathrm{a}$ \\
\hline 3-Raw wheat germ $(5 \%)$ & $52.94 \pm 2.76 \mathrm{~b}$ & $24.77 \pm 2.66 \mathrm{~b}$ & $11.58 \pm 1.26 \mathrm{~b}$ \\
\hline 4- Fermented wheat germ $(5 \%)$ & $42.51 \pm 1.86 \mathrm{bc}$ & $26.65 \pm 1.86 \mathrm{a}$ & $10.73 \pm 1.11 \mathrm{~b}$ \\
\hline 5- Raw Wheat germ $(10 \%)$ & $46.41 \pm 1.09 \mathrm{bc}$ & $26.26 \pm 1.80 \mathrm{ab}$ & $9.33 \pm 1.50 \mathrm{~b}$ \\
\hline 6- Fermented wheat germ $(10 \%)$ & $37.95 \pm 1.14 \mathrm{c}$ & $27.12 \pm 2.13 \mathrm{a}$ & $9.47 \pm 1.64 \mathrm{~b}$ \\
\hline 7- Raw Wheat germ (15\%) & $38.04 \pm 1.65 \mathrm{c}$ & $27.22 \pm 1.64 \mathrm{a}$ & $8.31 \pm 0.98 \mathrm{c}$ \\
\hline 8 - Fermented wheat germ $(15 \%)$ & $34.41 \pm 1.34 \mathrm{c}$ & $29.24 \pm 1.33 \mathrm{a}$ & $7.79 \pm 0.89 \mathrm{c}$ \\
\hline
\end{tabular}

* Values with the same letters indicate non significant difference $(\mathrm{P}<0.05)$ and vice versa.

Also, it could be observed that all cirrhotic groups fed on basal diet containing different levels of raw or fermented wheat germ $(5,10$ and $15 \%)$ had significant decrease in serum low density lipoprotein (LDL), very low density lipoprotein (vLDL) and increase in serum high density lipoprotein (HDL) compared with control positive rats . The best treatment was fermented wheat germ (15\%) and raw wheat germ at the same level, which had the lowest value of serum low density lipoprotein (LDL), very low density lipoprotein (vLDL) and the highest value of serum high density lipoprotein (HDL) .

Our findings are in line with that of Cesare et al., (2006) (52), who concluded that wheat germ oil is an important source of n-3 fatty acids, which may exert an antiatherosclerotic effect via inhibition of oxidative stress-mediated CD40L upregulation. 
Liver enzymes activities were used as important biomarkers for detection of hepatotoxic. Four serum hepatic marker enzymes (ALT, AST and ALP) were evaluated for hepatotoxicity. The liver is the most sensitive organ to preoxidative damage because it is rich in oxidizable substances. The increment of the oxidative stress on the cells of the liver and the consequent decrease in the antioxidant ability of the cells result in the occurrence of aggressive cellular damage to the liver cells with destruction of their membranes and the release of the enzymes into the blood stream .The more severe the liver damage the higher the release of the liver enzymes (53). The increased levels of serum enzyme such as AST and ALT indicate the increased permeability and damage or necrosis of hepatocytes (54) . The membrane bound enzymes like ALP and $\gamma \mathrm{GT}$ are released unequally into bloodstream depending on the pathological phenomenon. The procyanidins found in grape can inhibit the apoptosis and damage of cells by oxygen free radicals (55) .

From data in table (5), it could be observed that cirrhotic rats (control positive group ) had significant increase in serum liver function and kidney function parameters ( AST, ALT, ALP, uric acid, urea and creatinine ) compared with the control negative group. Also, it could be observed that all cirrhotic groups fed on basal diet containing raw or fermented wheat germ in different levels $(5,10$ and $15 \%)$ had significant decrease in serum liver function parameters (AST,ALT and ALP) and serum kidney function parameters (uric acid, urea and creatinine ) compared with the control positive group rats. The results was in agreement with previous authors Yuguang et al., (2004) (56) who reported that the potential short-term adverse effects of concentrated wheat germs policosanol (WGP) when used as a supplement, caused no adverse effects in the volunteers as indicated by plasma hepatic enzyme activities. For each volunteer, the activities of plasma ALT, AST, and $\gamma \mathrm{GT}$ were within the normal range at the beginning and the end of the trial. 
Table (6) : Effect of raw and fermented wheat germ on Serum levels of interferon gamma(INF- $\gamma$ ) and interleukin-10 ( IL-10 ) $(\mathrm{pg} / \mathrm{mL})$.

\begin{tabular}{|c|c|c|}
\hline Parameters & $\begin{array}{l}\text { INF- } \gamma(\mathrm{pg} / \mathrm{mL}) \\
\text { Mean } \pm \text { S.D. }\end{array}$ & $\begin{array}{l}\text { IL }-10(\mathrm{pg} / \mathrm{mL}) \\
\text { Mean } \pm \text { S.D. }\end{array}$ \\
\hline 1- Control Negative & $31.97 \pm 2.86 \mathrm{~d}$ & $21.00 \pm 3.49 \mathrm{~b}$ \\
\hline 2- Control Positive & $24.29 \pm 2.55 \mathrm{e}$ & $17.42 \pm 3.58 \mathrm{c}$ \\
\hline 3-Raw wheat germ (5\%) & $34.71 \pm 2.88 \mathrm{~d}$ & $20.19 \pm 2.45$ bc \\
\hline 4- Fermented wheat germ (5\%) & $62.00 \pm 3.65 \mathrm{c}$ & $25.29 \pm 4.18 b$ \\
\hline 5- Raw Wheat germ (10\%) & $37.59 \pm 5.77 \mathrm{~d}$ & $22.71 \pm 3.88 \mathrm{~b}$ \\
\hline 6- Fermented wheat germ $(10 \%)$ & $97.00 \pm 4.78 b$ & $37.00 \pm 3.95 \mathrm{a}$ \\
\hline 7- Raw Wheat germ (15\%) & $69.70 \pm 5.33 c$ & $23.29 \pm 2.89 b$ \\
\hline 8- Fermented wheat germ (15\%) & $112.23 \pm 6.11 a$ & $38.86 \pm 4.34 \mathrm{a}$ \\
\hline
\end{tabular}

* Values with the same letters indicate non significant difference $(\mathrm{P}<0.05)$ and vice versa.

From data in table (6), it could be observed that cirrhotic rats (control positive group ) had significant decrease in serum level of interferon gamma (INF-y) and interleukin -10 (IL-10) compared with control negative group. Also, it could be observed that all cirrhotic groups fed on basal diet containing raw or fermented wheat germ at different levels $(5,10$ and $15 \%)$ had significant increase in serum level of interferon gamma (INF-y) and interleukin -10 (IL-10) compared with control positive group rats.

This might be due to the fact that wheat germ is rich source of dietary fibers, vitamins, minerals and phytochemicals including phenolics, carotenoids, vitamin E, lignans, $\beta$-glycan,inulin, resistant starch sterol and phytates (57) . Deficiencies of its, for any reason, affect all components of immunity. Among the causes deficiency are an inadequate diet, impaired digestion and /or absorption, altered metabolism, a disease state, increased utilization of a nutrient and increased need for a nutrient. Excesses of specific nutrient can also alter immune function. Certain nutrients, including vitamins $\mathrm{C}$ and $\mathrm{E}$, affect various parts of immune function when present in excess (58) .The effects of malnutrition on immunity had been extensively studied and were well documented (59). In case of protein energy malnutrition there is increased morbidity and mortality from infections due to suboptimal immune systems. The increased rate of infection and death in protein energy malnutrition is due to the inability of the immune system to resist and/or effectively fight the infection. Without adequate vitamin $E$ the immune system does not function normally. Phagocytosis as well as cell 
mediated and humoral immunity are all impaired. Vitamin E supplementation appears to enhance immunity and resistance to infections in animals and quite possibly humans (60).Vitamin $\mathrm{E}$ has immune functions beyond its role as an antioxidant, such as regulation the synthesis of eicosanoids on immune cell membranes, keeping the cells from overproducing eicosanoids. When vitamin $\mathrm{E}$ is deficient, production of the immunosuppressive PGE, is increased, which impairs immune function (61) .Vitamin E supplementation increase differential count (lymphocytes and monocytes) ( 62) .On the other hand, vitamin E deficiency induces the decrease differentiation of immature $\mathrm{T}$ cells which results in the early decrease of cellular immunity (63) . Vitamin E enhances some measures of immune-cell activity in the elderly(64). This effect was more pronounced with 200 IU per day, while under 200 IU per day had not boosted immune function in some reports ( 65) . Beta-carotene and other carotenoids had increased immune cell numbers and activity in animal and human research. An effect that appears to be separate from their role as precursors to Vitamin A(66) .

The best results in our study were found in all groups fed fermented wheat germ at different levels $(5,10,15 \%)$ which had the highest values of serum level of interferon gamma (INF-y) and interleukin -10 (IL-10) respectively .This might be due to that the nutritive quality or digestibility of plant protein is affected by the presence of anti-nutritional factors such as proteinase inhibitors, specially trypsin and chymotrypsin inhibitors (67). Several conventional processing methods, such as soaking and fermentation had been used to inactivate these undesirable components from plant seeds (68).

Avemar is the product of industrial fermentation of wheat germ. Since its invention, a series of in vitro and in vivo studies and clinical trials had been carried out to determine whether Avemar could help cancer patients struggling with both the effects of their disease and the side effects of standard anticancer therapy (SAT). Subsequently, evidence of the efficacy of the fermented wheat germ extract in some autoimmune diseases had also been found (69) .

\section{Histopathological examination:}

Microscopicall examination of liver of rat in negative control group , showing the normal histological structure (photol). While microscopicall examination of liver of cirrhotic rats fed on basal diet with Subcutaneous 
injection by Ccl4 (control positive) showing more severe and prolonged degeneration alteration, swelling of hepatocytes (Photo 2). In addition, microscopic examination of liver of cirrhotic rats when fed raw or fermented wheat germ at different levels $(5,10$ and $15 \%)$ show fatty change of hepatocytes in rats fed on raw wheat germ 5\% (photo 3) and small vacuoles in the cytoplasm of hepatocytes for rats fed on raw wheat germ $10 \%$ (photo 4 ), while showing only a slight alteration in hepatocytes in rats fed on raw wheat germ $15 \%$ (photo 5). Moreover, showing only apparent normal histological structure in hepatocytes of rats fed on fermented wheat germ 10 and $15 \%$, while showing mild Degeneration alteration and mild swelling of hepatocytes of rats fed on fermented wheat germ 5\% (Photo 6) . This might be due to increased levels of serum enzyme such as AST and ALT indicate the increased permeability and damage or necrosis of hepatocytes (54) .

Conclusion: It could be concluded that wheat germ and fermented wheat germ improve some Immunoglobulin's production, lipids profile and liver functions especially fermented wheat germ 10 and $15 \%$ which has a best significant protective effect against acute hepatotoxicity induced by carbon tetrachloride (Ccl4) in rats, which may be due to its free radical scavenging effect and its ability to increase antioxidant activity.

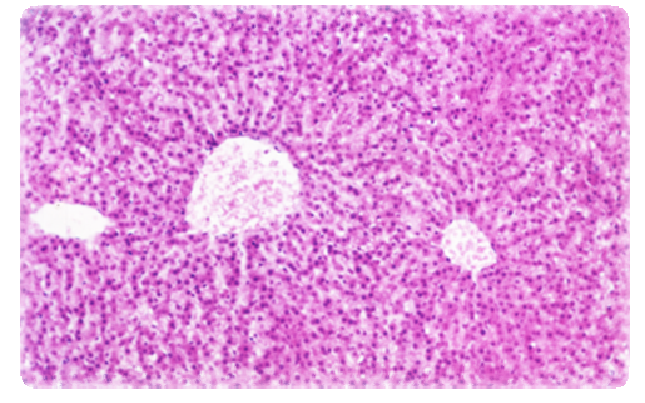

photo (1): Microscopicall examination of liver of rat in negative control group, showing the normal histological structure.

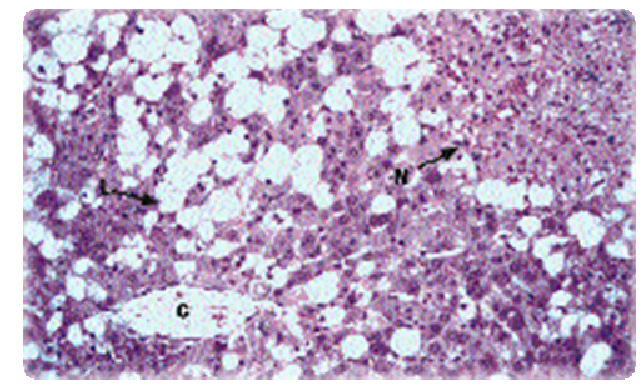

Photo (2): Microscopicall examination of liver of rats fed on basal diet with Subcutaneous injection by Ccl4 (control positive) showing more sever and prolonged degeneration alteration, swelling of hepatocytes . 


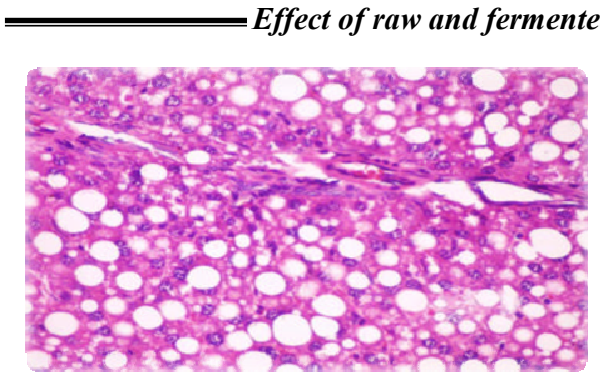

Photo (3) : Microscopicall examination of liver of rats fed on basal diet with Subcutaneous injection by $\mathrm{Ccl} 4$ and administrated with raw wheat germ5\% showing fatty change of hepatocytes .

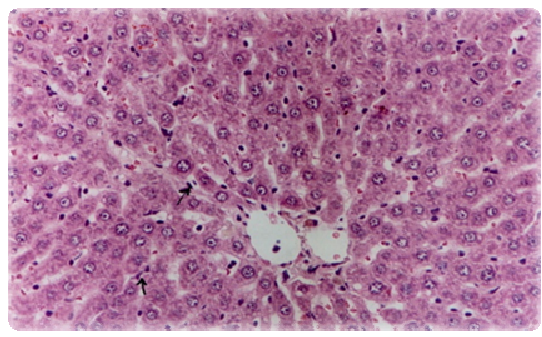

Photo (5) : Microscopicall examination of liver of rats fed on basal diet with Subcutaneous injection by $\mathrm{Ccl} 4$ and administrated with raw wheat germ $15 \%$ showing only a slight alteration in hepatocytes.

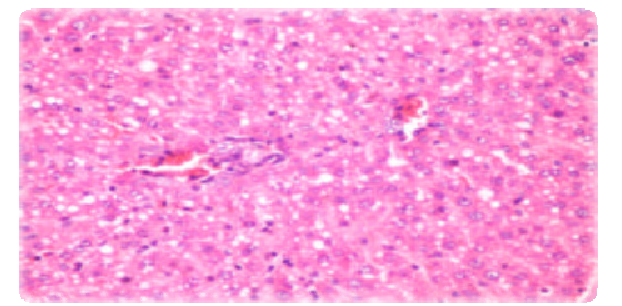

Photo (4) : Microscopicall examination of liver of rats fed on basal diet with Subcutaneous injection by $\mathrm{Ccl} 4$ and administrated with raw wheat germ $10 \%$ showing small vacuoles in the cytoplasm of hepatocytes

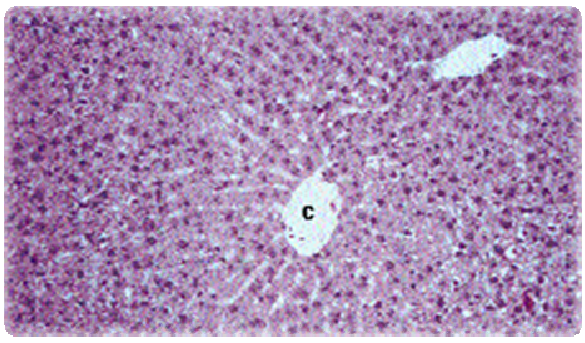

Photo (6): Microscopicall examination of liver of rats fed on basal diet with Subcutaneous injection by $\mathrm{Ccl} 4$ and administrated with fermented wheat germ 5\% showing mild Degeneration alteration and mild swelling of hepatocytes 
References :

1. H.E. Poulson, H. Prieme and S. Loft(1988). Role of oxidative DNA damage in cancer initiation and promotion, Eur J Cancer Prev 7, pp. 9-16.

2. R. Govindarajan, M. Vijayakumar and P. Pushpangadan (2005). Antioxidant approach to disease management and the role of 'Rasayana' herbs of Ayurveda, J Ethnopharmacol 99, pp. 165-178.

3. Ramasamy Anandan, Balasun daram Jayakar, Biusan Karar,Seevalen Babuji, Rajappan Manavalan And Raju Senthil Kumar (2009): effect of ethanol extract of flowers of vitex trifolia linn. on ccl4 induced hepatic injury in rats .pak. j. pharm. sci., vol.22, no.4, pp.391-394.

4. Nichelatti, M. and M. Hidvegi, 2002. Experimental and clinical results with Avemar (a dried extract from fermented wheat germ) in animal cancer models and in cancer patients. Nogyogyaszati Onkologia; 7: 180-185.

5. Holland, B., A.A. Welch, I.D. Unwin, D.H. Buss, A.A. Paul and D.A. Southgate, 1991. The composition of foods. The Royal Society of Chemistry Cambridge. In McCance and Widdowsons.

6. Yiqiang, G., S. Aidong, N. Yuanying and C. Tongyi, 2001. Study and development of a defatted wheat germ nutritive noodle. Eur. Food Res. Technol., 212: 344-348.

7. Sjovall, O.; Virtalaine, T.; Lapvetelainen, A.M. and Kallio, H. (2000). Development of rancidity in wheat germ analyzed by headspace gas chromatography and sensory analysis. Journal of Agricultural and Food Chemistry, 48(8): 3522-3527.

8. Liu, R. H.,(2007) . Whole grain phytochemical and health .J. Cereal Sci,46; 207-219.

9. Diplock, A. (1995). Safety of antioxidant vitamins and B-carotein, Am J Clin Nutr.,62(suppl):1510s -1516s .

10. Wood ,R. (1999). The new whole food encyclopedia. New York: Penguin Books.

11. Jayaraj, A. P. ; Tovey, F. I. ;Clork, C. g. and Hobsley, M. (2001). Gastroent. Hepatol., 16 (5), 501.

12. USDA (2006). Oil, wheat germ, National Nutrition Database for Standard Reference, 1 .

13. Reeves , P.G; Nielsen , F.H. and Fahmy , G.G. (1993). AIN-93. Purified diets for laboratory rodents : Final report of the American Institute of Nutrition 
adhoc wriling committee on the reformulation of the AIN-76 A Rodent diet . J. Nutrition , 123: 1939-151.

14. Wilfried,F.; Anne Bosma,F.; Hendriks,J.; Rohol,E. and Dick,.(1994). Vitamin A deficiency potentiates carbon tetrachloride induced liver fibrosis in rats., J of Hepathology, 19(1):193-201.

15. Allain, C.C.; Poon, L.S. and Chan, C.S., Enzymatic determination of total serum cholesterol . Clin . Chem. , .(1974) 20, 470-475.

16. Wahlefeld, A.W., Enzymatic Determination of Triglycerides .Methods of Enzymatic Analysis . (1974)Vol. 5 , HU. Bergmeyer, Ed. Academic Press, New York, pp. 1831-1835.

17. Albers, N.; Benderson, V. and Warnick, G. ,Enzymatic determination of high density lipoprotein cholesterol : Selected Methods .Clin. Chem., (1983) 10:91-99.

18. Fridewald , W.T.; Leve, R.I. and Fredrickson , D.S .,Estimation of the concentration of low density lipoprotein . Clin. Chem. (1972) 18:499-502.

19. SAS (1996),Statistical Analysis System, ASA User's Guide : Statistics . SAS Institute Inc. Editors, Cary, NC.

20. Schmit , J.M. (1964).Colorimetric Determination of Total Lipids Using Sulfophosphovanilic Mixture . Thesis, Lyon Biomerieurx - Comp. of France .

21. Reitman,S.and Frankel,S.(1957): Determination of glutamate pyruvate transferase. Amer. J . Clin.Path.,28,32-33.

22. Patton,C.J.and Crouch,S.R.(1977):Enzymatic calorimetric method to determine urea in serum. Anal.Chem.,49,464-469.

23. Fossati,P.;Prencipe,L.and Berti,G.(1980):Enzymatic colorimetric method of determination of uric acid in serum. Clin.Chem.,26(2),227-237.

24. Husdan,H.and Rapoport,A. (1968):Estimation of creatinine by Jaffe reaction. Clin.Chem., 14,222-228.

25. Staehelin, T., Stähli, C., Hobbs, D.S., and Pestka, S. (1981) "A Rapid Quantitative Assay of High Sensitivity for Human Leukocyte Interferon with Monoclonal Antibodies," in Methods in Enzymology, Vol. 79 (S. Pestka, ed.), Academic Press, New York, 589-595.

26. Kelder, B., Rashidbaigi, A., and Pestka, S. (1986) "A Sandwich Radioimmunoassay for Human IFN- $\gamma$," in Methods in Enzymology, Vol. 119 (S. Pestka, ed.), Academic Press, New York, 582-587.

27. Human IFN- $\gamma$ international reference standard provided by the NIH, reference no. Gg23-901-530. Pestka, S. (1986) "Interferon Standards and General Abbreviations," in Methods in Enzymology, Vol. 119 (S. Pestka, ed.), Academic Press, New York, 14-23. 
28. Kung, H. -F., Pan, Y.-C., Moschera, J., Tsai, K., Bekesi, E., Chang, M., Sugino, H., and Honda, S. (1986). "Purification of Recombinant Human Immune Interferon," Methods in Enzymology, Vol. 119 (S. Pestka, ed), Academic Press, New York, 204-210.

29. Croce, M.A., et al. (1998). Partial liquid ventilation decreases the inflammatory response in the alveolar environment of trauma patients. J. Trauma 45, 273-282.

30. Greig, P., et al. (1995). Elevated amniotic fluid interleukin-10 concentrations increase through pregnancy are elevated in patients with preterm labor associated with intrauterine infection. Amer. J. Obstet. Gynecol. 173, 1223- 1227.

31. Komorowski, J., et al. (1998). Cytokine serum levels as the markers of thyroid activation in Graves' disease. Immunol. Lett. 60, 143-148.

32. Koziel, M.J., et al. (1995). HLA class I-restricted cytotoxic T lymphocytes specific for hepatitis $\mathrm{C}$ virus. Identification of multiple epitopes and characterization of patterns of cyokine release. J. Clin. Invest. 96, 2311-2321.

33. Platz, K., et al. (1996). Cytokine pattern during rejection and infection after liver transplantation - improvements in postoperative monitoring? Transplantation 62, 1441-1450.

34. Schultze, J.L., et al. (1997). CD40-activated human B cells: an alternative source of highly efficient antigen presenting cells to generate autologous antigen- specific $\mathrm{T}$ cells for adoptive immunotherapy. J. Clin. Invest. 100, 2757-2765.

35. Whitcup, S.M., et al. (1997). Association of interleukin 10 in the vitreous and cerebrospinal fluid and primary central nervous system lymphoma. Arch. Ophthalmol. 115, 1157-1160.

36. Zhang, Y., et al. (1997). Secretory leukocyte protease inhibitor suppresses the production of monocyte prostaglandin $\mathrm{H}$ synthase-2, prostaglandin $\mathrm{E} 2$, and matrix metalloproteinases. J. CLin. Invest. 99, 894-900.

37. Carleton,H.(1979). Histological Techniques 4th Ed. London, Oxford University press ,New York, Toronto .

38. Klimes, J.; Jedlicka, A.; Determination of Water- and Fat-Soluble Vitamins in Different Matrices UsingHigh-Performance Liquid Chromatography,Chem. Pap., 2005, 59, 202-222.

39. Ranjbar, A.H., F.J. Solhi, A. Mashayekhi and M. Abdollahi, 2005. Oxidative stress in acute human poisoning with organophosphorus insecticides; a case control study. Environ. Toxicol. Pharmacol., 20: 88-91.

40. Abdollahi, M., A. Ranjbar, S. Nikfar and A. Rezaie, 2004. Pesticides and oxidative stress a review. Med. Sci. Monit., 10: 141-147. 
41. Gupta, R.C., 2006. Toxicology of Organophosphates and Carbamate Compounds. Elsevier Academic Press,USA, London, UK.

42. Vaher, M., K. Matso, T. Levandi and M. Kaljurand, 2010. Phenolic compounds and the antioxidant activity of the bran, flour and whole grain of different wheat varieties. Procedia Chem., 2: 76-82.

43. Ge, Y., A. Sun, Y. Ni and T. Cai, 2001. Study and development of a defatted wheat germ nutritive noodle. European Food Res. and Techn., 212: 344-348.

44. Zhu, K., H.M. Zhou and H.F. Qian, 2006. Proteins extracted from defatted wheat germ, nutritional and structural properties. Cereal Chem., 83: 69-75.

45. Mansour, S.A. and A.H. Mossa, 2010. Adverse effects of exposure to low doses of chlorpyrifos in lactating rats. Toxicol Ind Health., 27(3): 213-224.

46. Gregorio, S.R., M.A. Areas and F.G. Reyes, 2001. Dietary 93. Rodent diet. J. Nutr., 123: 1939-1951. fibers and cardiovascular disease. 22: 109-120.

47. Borel P, Lairon D, Senft M, Chautan M, Lafont H. Wheat bran and wheat germ: effect on digestion and intestinal absorption of dietary lipids in the rat. Am J Clin Nutr 1989;49:1192-202.

48. Lairon D, Lacombe C, Borel $\mathrm{P}$, et al. Beneficial effect of wheat germ on circulating lipoproteins and tissue lipids in rats fed a high cholesterolcontaining diet. J Nutr 1987;117:838-45.

49. Cara L, Dubois C, Borel P, et al. Effects of oat bran, rice bran, wheat fiber, and wheat germ on postprandial lipemia in healthy adults. Am J Clin Nutr 1992;55:81-8.

50. Lairon D, Borel P, Termine E, Grataroli R, Chabert C, Hauton JC. Evidence for a proteinic inhibitor of pancreatic lipase in cereals, wheat bran and wheat germ. Nutr Rep Int 1985;32:1107-13.

51. Cara L, Borel P, Armand M, et al. Effects of increasing levels of raw or defatted wheat germ on liver, feces and plasma lipids and lipoproteins in the rat. Nutr Res 1991;11:907-16.

52. Cesare Alessandri, Pasquale Pignatelli, Lorenzo Loffredo, Luisa Lenti, Maria Del Ben, Roberto Carnevale, Alessandro Perrone, Domenico Ferro, Francesco Angelico, Francesco Violi ,(2006). Alpha-Linolenic Acid-Rich Wheat Germ Oil Decreases Oxidative Stress and CD40 Ligand in Patients With Mild Hypercholesterolemia. Arterioscler Thromb Vasc Biol , 26:2577-2578.

53. El-Khayat, Z., R.E. Ahmed, S.A. Mahmoud, I.R. Wafaa and R.E. Tahany, 2009. Potential effects of bee honey and propolis against the toxicity of ochratoxin A in rats. Maced. J. Med. Sci., 2(4): 311-318.

54. Pari, L. and S. Arumugam, 2008. Effect of grape (Vitis vinifera L.) leaf extract on alcohol induced oxidative stress in rats. Food and Chemical Toxicol., 46: 1627-1634. 
55. Li, L. and J. Zhong, 2004. Effect of grape procyanidins on the apoptosis and mitochondrial transmembrane potential of thymus cells. J. of Hygiene Res., 33: 191-194.

56. Yuguang, L., R. Mike, A. Trautwein and W. Gert, 2004. Wheat Germ Policosanol failed to lower plasma cholesterol in subjects with normal to mildly elevated cholesterol concentrations. Metabolism., 53: 1309-1314.

57. Liu, R. H.,(2007) ; Whole grain phytochemical and health .J. Cereal Sci,46; 207-219.

58. Bowers, J. (2002) : Nutrition and immunity, You Are What You Eat. Vol. 11, No.2.

59. Scrimshaw, N. (1997) : Synergism or nutrition, infection and immunity: an overview", Am J Clin Nutr., 8(4): 177-83.

60. Meydani, S. (1996) : Effect of (n-3) polyunsaturated fatty acids on cytokine production and their biologic function, Nutrition, 12:S8-S14.

61. Bendich, A. (1990): Antioxidant vitamins and their functions in immune responses. Adv Exp Med Biol, 262:35-55.

62. Abdel Ghafar,N. M. (2004) : Effect of Zinc and vitamin E on immune system of rats. Ph. D Thesis,Faculty of Home Economic, Helwan University.

63. Moriguchi, S. and Muraga, M.(2000): vitamin E and immunity, Vitamin Horm, $59: 305-36$.

64. Meydani, S. N; Barklund, M. P ;Liu, S.; Meydani, M. ;Miller, R.A.; Cannon, J.G.; Morrow, F.D.; Rocklin, R . and Blumberg, J.B.(1990) : Vitamin E supplementation enhances cell-mediated immunity in healthy elderly subjects. Am J Clin Nutr ,52:557-63.

65. De Waart, F. G, Portengen L, and Doekes G.(1997):Effect of 3 months vitamin E supplementation on indices of the cellular and humoral immune response in elderly subjects. Br J Nutr, 78:761-74.

66. Chew, B.P. (1993) :Role of carotenoids in the immune response. J Dairy Sci.; 76: 2804-11.

67. Abu-Tarboush, H.M. and Ahmed, S.B. (1996): Studies on Karkade (Hibiscus sabdariffa): protease inhibitors, phytate, in vitro protein digestibility and gossypol content. Food Chem., 56, 15.

68. Hassan, I.A.G. and EI-Tinay, A.H. (1995): Effect of fermentation on tannin content and in vitro protein and starch digestibilities of two sorghum cultivars. Food Chern, 53, 149.

69. Boros, L. G; Nichelatti, M and Shoenfeled Y. (2005): Fermented wheat germ extract (Avemar) in the treatment of cancer and autoimmune diseases, Ann. N. Y. Acad Sci. Jum. 1051: 529-42. 
تأثير جنين القهح الخام والمتخهر علي الأكسدة والمناعة الناتجة هن تسهم الكبد في الفئران برابع كلوريد الكربون

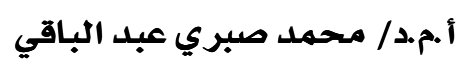

قسم التغذية وعلوم الأطعمهة - كلية الاقتصاد المنزلي - جامعة حلوان

ملخص :

أجريـت هـذه الدراسـة لتقيـيم تأثير جـنين القمـح الخـام والمتخمـر على انتـاج الاجسام المناعيـة

الدهون ووظائف الكبد يِّ الفئران المصابة بتليف الكبد بـ Cc14. وقد تم تقسيم الفئران إلى ثهاني

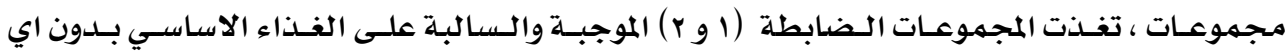
اضافات ـوتغذت جميع المجموعات المصابة بتليف الكلبد (^:^) على الغذاء الاساسي المضاف اليه جنين

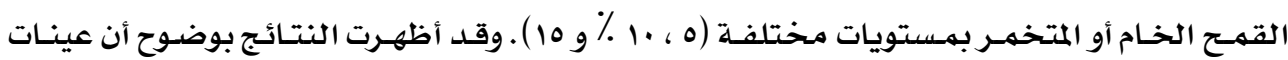

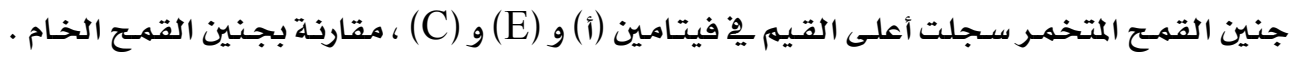

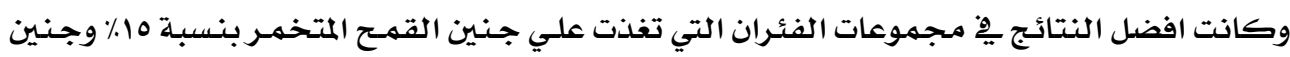

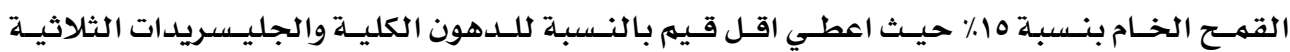
والكوليستيرول والليبوبروتينات منخفضة الكثافة كهما اعطت اعلـي القيم هِّ الليبوبروتينـات مرتفعـة

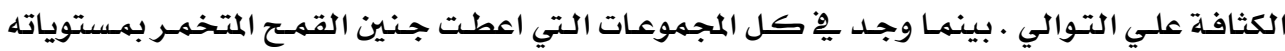

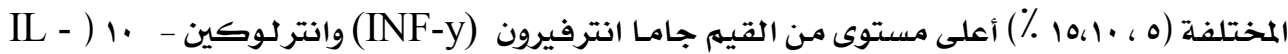
10) على التوالي. ويمكن أن نخلص إلى أن جنين القمح الخام وجنين القمح المخمرة تؤدي الي تحسين

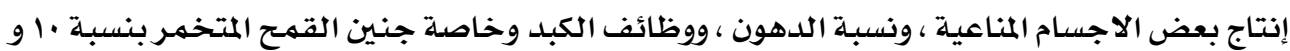

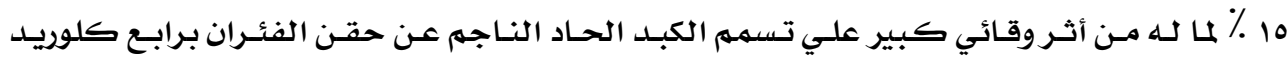
الكريون CCl4

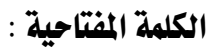
جــين القهـح المتخهـر - تليـف الكبـد - CCl4 - الإجهـاد التأكسدي الكبـد - الجهـاز 